\title{
Conference on Sierra Nevada Meteorology of the American Meteorological Society and the USDA Forest Service, June 19-21, 1978, South Lake Tahoe, Calif.
}

\section{AMS National Officers President: George P. Cressman President-Elect: Chester W. Newton Executive Director: Kenneth C. Spengler}

\author{
AMS Northern Nevada \\ Chapter
}

AMS Sacramento
Chapter

Program Committee

Synopsis of Sessions

\section{General Information}

Chairman: John Houghton

Vice-Chairman: Lawrence P. Kierulff

Chairman: Percy Edwards
Secretary: Paul Fransioli

Treasurer: Dennis Lamb

Vice-Chairman: Charles D. Unger Secretary-Treasurer: Freeman Smith
Douglas G. Fox

Peter F. Lester

Morris H. McCutchan
Bill C. Ryan

James L. Smith

\author{
June 18, Sun., \\ June 19, Mon., 8:00 a.m. Registration (continued) \\ Mon., 8:30 a.m. Welcome and Introductory Remarks \\ Mon., 8:45 a.m. Session 1: Analyzing and Forecasting Mountain \\ Weather \\ Mon., 1:00 p.m. Session 2: Mountain Air Quality \\ Mon., 3:30 p.m. Session 3: Mountain Winds 1-Analysis \\ Mon., 6:00 p.m. Icebreaker \\ June 20, Tues., 8:30 a.m. Session 4: Mountain Winds 2-Modeling \\ Tues., 1:00 p.m. Session 5: Mountain Winds 3-Waves, Severe Winds, \\ and Turbulence \\ Tues., 5:30 p.m. Guest Lecture/Dinner \\ June 21, Wed., 8:30 a.m. Session 6: Sierra Precipitation 1-Analysis \\ Wed., 1:00 p.m. Session 7: Sierra Precipitation 2-Sierra Cooperative \\ Project
}

The American Meteorological Society and the USDA Forest Service will hold a Conference on Sierra Nevada Meteorology, 19-21 June 1978, at the Waystation in South Lake Tahoe, Calif. The AMS Northern Nevada Chapter and the AMS Sacramento Chapter will be the local hosts.

\section{Hotel}

All sessions will be held in the Tahoe Room of the Waystation. A block of rooms has been set aside for the meeting at the following special rates: $\$ 26$, single; $\$ 28$, double (plus 6\% tax). Kindly make your reservations prior to 20 May 1978 by writing directly to: The Waystation, P.O. Drawer 1267, South Lake Tahoe, Calif. 95705 (tel: 916-541-6220, California Toll Free: 800-822-5962). Be sure to mention the American Meteorological Society's name when making reservations. 


\section{Registration}

\section{Transportation}

\section{Icebreaker}

Guest Lecture/Dinner

\section{Spouses' Activities}

\section{PROGRAM}

\section{Sun., June 18,} 6:00 p.m.

\section{Mon., June 19, 8:00 a.m.}

Mon., June 19, 8:30 a.m.

\section{Mon., June 19, 8:45 a.m.}

The AMS registration desk will be open Sunday, 18 June, from 6:00 p.m. to 8:00 p.m. and on Monday through Wednesday from 8:00 a.m. to 5:00 p.m. Registration fee, including preprint volume and guest lecture/dinner, is $\$ 35$. We urge you to preregister by sending your remittance together with your name, affiliation, and complete mailing address to: American Meteorological Society, 45 Beacon St., Boston, Mass. 02108, Attn: Conference on Sierra Nevada Meteorology. The preprint volume will be sent to those preregistrants whose remittances are received prior to 5 May 1978.

The Waystation provides courtesy service to and from Tahoe Valley Airport. Air California and Pacific Southwest Airlines serve Tahoe Valley Airport from major California cities with frequent daily flights. United, Hughes Air West, and Western Airlines serve Reno International Airport, which is $55 \mathrm{mi}$ away. Car rentals are available from Arrow Rent-R-Car located in the lobby of the Waystation, and through various other agencies. Arrow offers a $\$ 6$ rebate on 3-day rentals. Reservations may be made through the Waystation; be sure to mention the AMS.

There will be an Icebreaker (cash bar) on Monday, 19 June, at 6:00 p.m.

There will be a conference beachside dinner (barbecue) preceded by a guest lecture on Tuesday, 20 June, at 5:30 p.m., and it is necessary that you sign-up in advance of this event by preregistering. Extra tickets may be purchased at $\$ 8.00$ each.

No formal activities are planned. The Waystation is located directly on the lake, with its own beach, pool, and facilities. Several public tourist attractions are located in the area, and information on these will be available at the conference.

\section{Registration}

\section{Registration (continued)}

\section{Welcome and Introductory Remarks}

Robert Z. Callaham, Director, Pacific Southwest Forest and Range Experiment Station/ USDA Forest Service, Berkeley, Calif.

\section{Session 1: Analyzing and Forecasting Mountain Weather}

Chairman: Thomas R. Crossan, National Weather Service/NOAA, Fresno, Calif.

Tahoe: A unique environmental setting. John W. James, Mountain West Weather Service and Sierra Nevada College, Incline; and John G. Houghton, Univ. of Nevada, Reno, Nev. (Invited Lecture)

Weather in wildland fire management-The Fire Weather Index. Michael A. Fosberg, Rocky Mountain Forest and Range Experiment Station/USDA Forest Service, Ft. Collins, Colo.

Diagnosing the diurnal variation of surface temperature using the maximum and minimum temperature. Morris H. McCutchan, Pacific Southwest Forest and Range Experiment Station/USDA Forest Service, Riverside, Calif.

Model output statistics in the western United States. William H. Klein, National Weather Service/NOAA, Silver Spring, Md.

A survey of severe weather events in the western United States. John F. Henz, GRD Weather Center, Denver, Colo. 
Mon., June 19, 1:00 p.m.

Mon., June 19, 3:30 p.m.

\section{Mon., June 19, 6:00 p.m.}

Tues., June 20, $8: 30$ a.m.
Testing of satellite uplinked remote surface weather stations in the Sierra Nevada. Donald Rottner, Bureau of Reclamation, Denver; and Gerald R. Price, Electronic Techniques, Inc., Ft. Collins, Colo.

\section{Session 2: Mountain Air Quality}

Chairman: Morris H. McCutchan, Pacific Southwest Forest and Range Experiment Station/USDA Forest Service, Riverside, Calif.

Downward transport of stratospheric ozone from a cold low during a heavy Sierra Nevada snowstorm. Thomas Y. Palmer, SWETL, Inc., Fallbrook, Calif.

Spatial distribution of primary automotive pollutants at Lake Tahoe. Thomas A. Cahill, Lowell L. Ashbaugh, John B. Barone, and Patrick J. Feeney, Univ. of California, Davis, Calif.

Studies of pollutant transport and turbulent dispersion over rugged mountainous terrain near Climax, Colo. John D. Reid, Atmospheric Environment Service, Downsview, Ont., Canada.

Nocturnal Central Valley pollution dynamics. Hans D. Giroux, W. R. Knuth, and J. A. Anderson, Meteorology Research, Inc., Altadena, Calif.

Pollutant concentrations and pollutant transport in the Great Central Valley and the Sierra Nevada. Charles D. Unger, California Air Resources Board, Sacramento, Calif.

\section{Session 3: Mountain Winds 1-Analysis}

Chairman: Peter F. Lester, San José State Univ., San José, Calif.

Influences on winds in mountainous terrain. Bill C. Ryan and J. Gregory Brown, Pacific Southwest Forest and Range Experiment Station/USDA Forest Service, Riverside, Calif.

Diurnal variation of winds at $3 \mathrm{~km}$ in the Sierra Nevada. Arnold Court, California State Univ., Northridge, Calif.

A pilot study of upslope winds in the Sierra Nevada. D. L. Morgan and W. F. Slusser, California State Univ., Fresno, Calif.

\section{Icebreaker}

\section{Session 4: Mountain Winds 2-Modeling}

Chairman: Douglas G. Fox, Rocky Mountain Forest and Range Experiment Station/ USDA Forest Service, Ft. Collins, Colo.

A three-dimensional numerical study of complex atmospheric circulation produced by terrain. Tetsuji Yamada, Argonne National Lab., Argonne, Ill.

Variational wind field adjustment over complex terrain using finite element techniques. D. R. Tuerpe and Philip M. Gresho, Lawrence Livermore Lab., Univ. of California, Livermore, Calif.; and R. L. Sani, Univ. of Colorado, Boulder, Colo.

Simulation of airflow over Lake Tahoe Basin. Arsi Vaziri, Desert Research Institute, Reno, Nev.

The NEWEST wind field model with applications to thermally driven drainage winds in mountainous terrain. Ralph C. Sklarew, Form \& Substance, Inc., Westlake Village, Calif. Effects of grid length on simulations of the surface wind in the Lake Tahoe region. Kit K. Wagner, Univ. of California, Davis, Calif.

Numerical modeling of wind fields over mountainous regions in California. $\mathrm{T}$. W. Tesche and M. A. Yocke, Systems Applications, Inc., San Rafael, Calif. 
Tues., June 20, 1:00 p.m.

Tues., June 20, 5:30 p.m.

Wed., June 21, $8: 30$ a.m.

Wed., June 21, 1:00 p.m.

\section{Session 5: Mountain Winds 3-Waves, Severe Winds, and Turbulence}

Chairman: James L. Smith, Pacific Southwest Forest and Range Experiment Station/ USDA Forest Service, Berkeley, Calif.

Observations of multiple layer inversions with gravity waves in a Sierra basin. Howard Dunsmore, Scientific Engineering Systems; and Paul Fransioli, Desert Research Institute, Reno, Nev.

The destruction of surface-based inversions by wind shear turbulence over northern Nevada. Tom Cylke, National Weather Service/NOAA, Reno, Nev.

Gravity wave and turbulent dispersion in a Sierra Nevada valley. Thomas Y. Palmer, SWETL, Inc., Fallbrook; and James A. Watrous, Univ. of California, Riverside, Calif.

Classical Sierra Nevada mountain wave-A triggering mechanism. Doug Armstrong, National Weather Service/NOAA, Reno, Nev.

A severe chinook windstorm. Peter F. Lester, San José State Univ., San José, Calif.

Operational prediction of damaging windstorms along the mountain ranges of the western United States. John F. Henz, GRD Weather Center, Denver, Colo.

\section{Guest Lecture/Dinner}

\section{Session 6: Sierra Precipitation 1-Analysis}

Chairman: Arnold Court, California State Univ., Northridge, Calif.

Orographic effects on Great Basin precipitation. John G. Houghton, Univ. of Nevada, Reno, Nev.

Historical climatology and snowpack response at Central Sierra Snow Laboratory. James L. Smith, Pacific Southwest Forest and Range Experiment Station/USDA Forest Service, Berkeley, Calif.

Snowpack evaporation reduction: It's possible, but is it practical? James A. Baldwin, Univ. of California; and James L. Smith, Pacific Southwest Forest and Range Experiment Station/USDA Forest Service, Berkeley, Calif.

Regionalizing design storms in data sparce areas of California. James D. Goodridge, California Dept. of Water Resources, Sacramento, Calif.

Lake Tahoe water balance. Rick A. Lind, California State Univ.; and James D. Goodridge, California Dept. of Water Resources, Sacramento, Calif.

Numerical calculations of airflow and cloud cover during winter storm conditions in the Colorado Rockies and the Sierra Nevada. E. C. Nickerson, D. R. Smith, and C. F. Chappell, Atmospheric Physics and Chemistry Lab./NOAA, Boulder, Colo.

\section{Session 7: Sierra Precipitation 2-Sierra Cooperative Project}

Chairman: Olin H. Foehner, Bureau of Reclamation, Denver, Colo.

Report on preliminary data from a multi-Doppler radar study of weather systems in and near the Sierra Nevada. W. R. Moninger, Wave Propagation Lab./NOAA; and Richard Carbone, NCAR, Boulder, Colo.

A radar climatology of Sierra Nevada windstorms. Joe L. Sutherland and Chester Wisner, North American Weather Consultants, Goleta, Calif.

Satellite support to the Sierra Cooperative Program. David W. Reynolds and Kenneth R. Morris, Colorado State Univ., Ft. Collins, Colo. 
Microphysical and dynamical characteristics of winter storms over the Sierra Nevada. John D. Marwitz and Ronald Stewart, Univ. of Wyoming, Laramie, Wyo.; and Larry Vardiman, Bureau of Reclamation, Denver, Colo.

A microphysics and synoptic study of the 14-15 December 1977 Sierra storm. James A. Moore, Bureau of Reclamation, Denver, Colo.

Preliminary meteorological measurements in support of the Sierra Cooperative Pilot Project. Larry Vardiman, Bureau of Reclamation, Denver, Colo.

\title{
ABSTRACTS
}

\author{
Session 1: Analyzing and forecasting mountain weather \\ Tahoe: $A$ unique \\ environmental setting \\ Abstract not available.
}

\section{J. W. JAMES AND \\ J. G. HOUGHTON}

Weather in wildland fire management-The Fire Weather Index

\section{A. FOSBERG}

Diagnosing the diurnal variation of surface temperature using the maximum and minimum temperature

\section{H. MCCUTCHAN}

Model output statistics in the western United States

\section{W. H. KLEIN}

A survey of severe weather events in the western United States

\section{J. F. HENZ}

The Fire Weather Index was developed to provide land managers with a picture of weather impact on fire behavior over time and space. This index is intended to supplement the National Fire-Danger Rating System and is based on the meteorological components of Byram's flame length equation. Wind speed, temperature, and relative humidity are numerically filtered through fuel moisture and fire spread concepts.

The Fire Weather Index is useful to land managers involved in fire dispatch, both as an index number and as a ratio of the current or forecast index to the value the index will achieve at the basic time fire danger levels are established.

The diurnal variation of surface temperature in mountainous terrain was modeled using the first two harmonics of the Fourier series. The temperature, $T$, at any time, $t$, is given by: $T_{t}=A_{0}+a_{1} \cos (\pi t / 12)+b_{1} \sin (\pi t / 12)+a_{2} \cos (\pi t / 12)+b_{2} \sin (\pi t / 6)$.

The Fourier coefficients $A_{0}, a_{1}, b_{1}, a_{2}$, and $b_{2}$ are all calculated independently of each other, making it possible to determine the coefficients individually by regression analysis. Stepwise screening regression was used to derive the Fourier coefficients. The potential predictors were the maximum, minimum, mean, and range of daily temperature; time of sunrise and sunset; and slope, aspect, and elevation of the station. The model was developed on data taken in the San Bernardino Mountains of southern California. Results of testing the model on $3 \mathrm{~h}$ temperature data from the Blue Canyon station in the Sierra Nevada will be presented.

Model output statistics (MOS) is a very effective technique for combining statistical and numerical weather prediction. MOS has been successfully applied by the National Weather Service to prepare automated guidance forecasts of numerous weather elements on the synoptic scale in all parts of the United States. This talk will emphasize the use of MOS in forecasting public weather (i.e., temperature, precipitation, clouds, and wind) in the western part of the country. To illustrate the method and its performance under operational conditions, sample forecast equations and teletypewriter output will be presented. The utility of MOS will then be evaluated with the aid of comparative verification figures.

A 10-year survey of the NOAA publication Storm Data was made for the 11 western states to rank the importance of severe weather events. Severe local storms of the West took the forms of terrain-induced windstorms, coastal windstorms, duststorms, firestorms, and flash floods in addition to more traditional occurrences of tornadoes, thunderstorm winds, and hail. Damage and fatalities caused by these storms have been steadily increasing, perhaps a reflection of the recent population growth history of the West.

The survey underscores the importance of developing a local prediction capability that can deal with a variety of mesoscale weather systems that produce the severe weather. Improved prediction of western severe local storms is needed due to the increasing population migration to the West, the proliferation of trailer parks near energy developments, and the popularity of the western states for winter and summer recreation. 
Testing of satellite uplinked remote surface weather stations in the Sierra Nevada

\section{ROTTNER AND}

G. R. PRICE
Two Automatic Environmental Surface Observation Platforms (AESOPs) were installed for a winter season for testing at relatively high elevations in the Sierra Nevada. The stations measure pressure, temperature, dew point temperature, averaged wind speed and direction, and precipitation. All surface data are relayed on the hour by the Geostationary Operational Environmental Satellite (GOES) at $135^{\circ} \mathrm{W}$ to Wallops Island, Va. The data are then automatically relayed to the Bureau of Reclamation's Engineering and Research Center, Denver, Colo., where they are merged with other NWS and FAA hourly surface data and are normally available 5-10 min after the hourly observation is taken.

The two AESOP sites in the Sierra Nevada were chosen to be Blue Canyon and the Central Sierra Snow Laboratory in order to compare the data to conventional manned observations as well as to test the reliability of the platforms. Both AESOPs were found to be reliable in the sometimes severe Sierra Nevada environment, and their observations were comparable to measurements taken by manned stations.

\section{Session 2: Mountain air quality}

Downward transport of stratospheric ozone from a cold low during a heavy Sierra Nevada snowstorm

\section{T. Y. PALMER}

There have been a number of surface measurements of high ozone levels (as great as $500 \mathrm{ppb}$ ) during precipitation, usually during heavy snow, and during the passage of a closed upper level low that has moved south from high latitudes.

Ozone and micrometeorological measurements at $2286 \mathrm{~m}$ elevation in the Sierra Nevada during a heavy snow $(50 \mathrm{~mm} / \mathrm{h})$ showed an hourly average of $124 \mathrm{ppb}$, and the spectrum of the concentration fluctuations were characteristic of a passive additive in the atmosphere. There was little vertical motion during this period. It is proposed that precipitation scavenging of stratospheric ozone near a folded tropopause, downward transport of the ozone in the precipitation, and subsequent release of the ozone at the ground as a result of changing $p H$, melting, and temperature are responsible for this and other observed high values.

Fine automotive lead provides an unambiguous tracer for gaseous and particulate emissions of automotive traffic. Thus, it can provide information on the spatial distribution of the impact of traffic on air quality in the Lake Tahoe air basin. Measurements have been made at numerous locations near Lake Tahoe that illustrate the important effects of mountain meteorology on air quality in the diurnal, synoptic, and seasonal time scales.

Tracer experiments were conducted in the vicinity of Climax, Colo., during the winters of 1973-74 and 1974-75 to investigate transport and turbulent dispersion in the mountain boundary layer. Tracer concentration patterns were observed by airborne detection of the ice nucleating properties of the silver iodide tracer.

Experimental techniques are outlined, and an analysis of data from a number of case study days is presented. The local transport-dispersion regime is found to be markedly influenced by terrain channeling and also by diabatically induced low-level motions. Some manifestations of the diabatic influence are: 1) tracer being found several kilometers "upwind" of the source, 2) long residence times for tracer in the stagnant nocturnal boundary layer flow, and 3) enhanced vertical transports of tracer in predominantly stable stratifications.

Implications of these observations for environmental assessments in mountainous regions are discussed.

A brief field program designed to study the role of the nocturnal valley jet on nighttime ventilation mechanisms of the San Joaquin Valley and the possible outflow over the Tehachapi Mountains was carried out during 9-11 September 1977. Vertical profiles and horizontal traverses were made in the field using an instrumented aircraft and two ground-level pilot balloon (pibal) stations. An analysis of the results indicates that the nocturnal jet maintains higher levels of ozone within it than would normally be expected at that altitude during nondaylight hours and that it may transport pollutants along the entire length of the valley and into the mountains to the south.

The transport of pollutants between the Great Central Valley of California and the Sierra Nevada is a subject of increasing importance. The effectiveness of an air management program is dependent on an understanding of the physical processes involved. The need to protect the human, agricultural, forestry, scenic, and recreational resources of this area from the adverse effects of air pollution needs hardly to be stressed.

During the last few years, a limited, but nevertheless useful, amount of air quality and meteorological data has been collected in this area. From these data and from an understanding
Pollutant concentrations and pollutant transport in the Great Central Valley and the Sierra Nevada

C. D. UNGER 
of the physical processes involved, a preliminary assessment of the spatial distribution of pollutant concentrations, and the effects of pollutant transport, can be made.

\section{Session 3: Mountain winds 1-Analysis}

Influences on winds in mountainous terrain

\section{B. C. RYAN AND}

J. G. BROWN

Diurnal variation of winds at $3 \mathrm{~km}$ in the Sierra Nevada

\section{A. COURT}

A pilot study of upslope winds in the Sierra Nevada

\section{L. MORGAN AND W. F. SLUSSER}

Winds in rugged terrain are produced and modified by a complex interaction of factors. Among these factors are: 1) influence of synoptic-scale conditions, 2) mesoscale flows such as the sea breeze, 3) valley winds, 4) slope winds, and 5) mechanical influences such as sheltering, diverting, funneling, and turbulence. In order to design the mathematical relationships to construct a simulated wind that matches the true wind, knowledge of the differing contributions of all these factors under a range of weather and topographic situations is needed. For this, statistics on wind speeds and directions at several stations in mountainous terrain for each month and at four times per day were analyzed and compared with topographic features.

Among the results of the analyses are the indicated strong influence of spur ridges and canyons and the significant sheltering and diverting of the sea breeze flow.

Wind behavior at $3 \mathrm{~km}$ above sea level in the central Sierra Nevada is not markedly different from that at much lower elevations. Maximum speeds come in early afternoon, rather than before midnight, as is sometimes assumed for mountains because of such behavior on Mt. Tamalpais, $800 \mathrm{~m}$ above the Golden Gate. Hourly values of wind speed and direction during 4 years (June 1968-June 1970 and July 1973-May 1975) have been extracted from strip charts from instruments at the radio relay station of the Southern California Edison Co. on Kaiser Ridge, $\sim 2.5 \mathrm{~km} \mathrm{NW}$ of Kaiser Peak, $80 \mathrm{~km}(50 \mathrm{mi}) \mathrm{NE}$ of Fresno, and $30 \mathrm{~km}$ (17 mi) west of the crest of the Sierra Nevada.

During the summer and fall of 1977 , continuous wind and temperature data were gathered from two mechanical weather stations placed in a remote area above timberline in Sequoia National Park. Interest in obtaining data of this nature stems from the paucity of quantitative information on the daily temperature and wind regimes of high mountain areas.

Preliminary analysis of these data shows verification of some important ideas. The influence of the synoptic wind on the diurnal local wind regime is quite complex, but definite relationships seem evident and expected seasonal changes in the timing and intensity of upslope-downslope winds occur.

\section{Session 4: Mountain winds 2-Modeling}

A three-dimensional numerical study of complex atmospheric circulation produced by terrain

\section{T. YAMADA}

Numerical simulations are performed in order to investigate complex atmospheric circulations produced by terrain. The model used is a second-moment turbulence closure model. As a first step toward including more complex and realistic terrain, numerical simulations of the airflow over single and multiple Gaussian-shaped mountains are studied.

Preliminary results for the case of a single, $500 \mathrm{~m}$ high Gaussian mountain indicate that horizontal wind speed in the lee of the mountain may increase, under some conditions, by $100 \%$ over that at the inflow boundary. Divergence and convergence of the horizontal wind field result in vertical motion through the continuity equation. A maximum downward motion of $200 \mathrm{~cm} \mathrm{~s}^{-1}$ is computed at $\sim 3.5 \mathrm{~km}$ above the mountain, while an upward velocity of only $20 \mathrm{~cm} \mathrm{~s}^{-1}$ is found at both upwind and downwind sides. Over the mountain, the potential temperature may increase as much as $10^{\circ} \mathrm{C}$, and the air can be much drier than that at the inflow boundary. These results are to be expected, for large subsidence is computed over the mountain, bringing down warmer (in terms of the potential temperature) and drier air.

We are developing a finite element mass-consistent model for wind fields over complex terrain that can serve as input for finite element transport and diffusion codes or as an assessment tool in wind power studies. The major advantage of a finite element model (vis-à-vis a conventional finite difference model) is that better topography resolution can be achieved through variable zoning of the grid. The model inputs are wind measurements interpolated to the grid point by an inverse square distance prescription; this interpolated wind field is then adjusted by a least squares technique and constrained to be mass consistent.
Variational wind field adjustment over complex terrain using finite element techniques

D. R. TUERPE ET AL. 
Simulation of airflow over Lake Tahoe Basin

\section{A. VAZIRI}

The NEWEST wind field model with applications to thermally driven drainage winds in mountainous terrain

\section{R. C. SKLAREW}

Effects of grid length on simulations of the surface wind in the Lake Tahoe region

\section{K. K. WAGNER}

Numerical modeling of wind fields over mountainous regions in California

T. W. TESCHE AND

M. A. YOCKE
A three-dimensional, mesoscale, primitive equation numerical model developed by Pielke (1974) for study of sea breeze circulations and tropospheric flow over irregular terrain has been employed to simulate the airflow patterns over the Sierra Nevada. The model is hydrostatic and includes topography, detailed boundary layer parameterization, and atmospheric radiative heating as well as surface heat budget calculations.

Simulations are performed for initial climatological data for the Lake Tahoe Basin. Particular emphasis is given to characterizing the effects of the terrain and Lake Tahoe on the prevailing flow.

Predicted flow fields and surface temperatures as a function of elevation are compared to some available observations.

The New Extensions to the WEST (Wind Extrapolated from Stability and Terrain) wind field model continues the original phenomenological development with a parameterization for thermally driven winds. Thus, NEWEST calculates a wind field that is nondivergent, has a stability dependent response to terrain, reproduces all ground-level and aloft wind measurements, and simulates the heating and cooling winds that often dominate the lowest layers in mountainous terrain. NEWEST was tested on 10 independent multihour data sets in a $5 \times 6 \mathrm{~km}$ mountainous area. NEWEST results were compared with observed winds and the measured transport of an inert tracer.

A single-layer diagnostic model of the surface wind flow is used to simulate the wind field in the Lake Tahoe region. The model incorporates the effects of terrain, surface friction, and mesoscale temperature and pressure patterns. The grid spacing is varied to discern its influence upon the wind vector and the divergence and vorticity patterns within the highly complex terrain of the region.

A new model has recently been developed for use in computing wind fields over rugged mountain topography. This grid-based model is founded upon the three-dimensional solution of the mass conservation equation. Unique in the model's formulation is the manner in which terrain effects (such as interactions between wind and topography, secondary thermal circulations, surface friction, and inversion capping) are explicitly included via physically based parameterization schemes.

Many potential applications of the model are identified, the most obvious being the study of air pollutant transport over mountainous terrain. The model might also be used, however, as an aid in avalanche hazard forecasting, the design of ski trails, placement of snow fences and jet roofs, cloud seeding activities, and prediction of the spread of wind-driven wildfires. Each of these potential applications is discussed.

\section{Session 5: Mountain winds 3-Waves, severe winds, and turbulence}

Observations of multiple layer inversions with gravity waves in a Sierra basin

\section{H. DUNSMORE AND \\ P. FRANSIOLI}

The destruction of surface-based inversions by wind shear turbulence over northern Nevada

\section{T. CYLKE}

Multiple layer low-level temperature inversions, often with gravity wave motions, have been observed in the Truckee Meadows (Reno) Basin by acoustic echo sounding. Examples of such inversions are discussed, and mechanisms for the formation of the multiple layers are presented. The gravity wave motions are analyzed with regard to wavelength, amplitude, phase velocity, and stability of the layers.

The formation of a nocturnal surface-based inversion is a common phenomenon in the late fall and winter months in mountain valleys during periods of fair weather. The destruction of these sometimes intense inversions by wind shear turbulence (i.e., gravity waves) was investigated over the Truckee Meadows and Humboldt River basins of Nevada.

A logarithmic regression analysis was performed, correlating the time after sunrise that the inversion broke with a computed Richardson number. Variables included a nondimensional bulk Richardson number derived from radiosonde and mountaintop wind data. Under certain conditions the winds aloft forecasts produced by the NMC primitive equation model (FD winds) can be used with satisfactory results. The results of this study reveal that the prediction of the time an inversion will break can be done satisfactorily to the benefit of aviation, air pollution, and public concerns. 
Gravity wave and turbulent dispersion in a Sierra Nevada valley

\section{T. Y. PALMER AND}

\section{J. A. WATROUS}

\section{Classical Sierra Nevada} mountain wave-A triggering mechanism

\section{ARMSTRONG}

A severe chinook windstorm

\section{P. F. LESTER}

Operational prediction of damaging windstorms along the mountain ranges of the western United States

\section{J. F. HENZ}

Diffusion experiments in which smoke and CO were released at Kirkwood Meadows in the Sierra Nevada were performed during both stable and unstable conditions. The low-level, cold air drainage flow down the valley was balanced by an up-valley flow above it up to the ridge level. Winds above this elevation were across the valley, $\sim 10 \mathrm{~m} / \mathrm{s}$. The average concentration isopleths during the $30 \mathrm{~min}$ experiments were essentially the same for both stable and unstable conditions.

Periods of the maximum energy in the power spectral density of the wind speed (290 s/cycle) closely agree with the observed period of the gravity waves (260 s/cycle) made visible by the smoke, as they moved back and forth across the valley. It is apparent that the vigourous early morning stirring was caused by the breaking of the gravity waves against the walls of the valley.

A very strong and turbulent Sierra wave condition that developed on Good Friday, 8 April 1977, is investigated as one feature of mountain meteorology. This case study was undertaken to determine the triggering meteorological phenomena that support development of the active Sierra wave. Interpreting a combination of meteorological information including analysis of atmospheric vertical cross sections, upper level constant pressure charts, and pseudoadiabatic diagrams with a series of NOAA-NESS weather satellite pictures chronologically depicting visible changes in wave cloud patterns leads to the conclusion that the triggering mechanism is inherent in the approach of a jet stream maximum wind impulse.

In this study, strong winds were observed during the day atop Slide Mountain near Lake Tahoe and Peavine Mountain near Reno, Nev. Aloft, numerous reports by powered aircraft of moderate to severe turbulence were noted. "Unpowered" sailplanes used the Sierra wave action to soar to altitudes above $23000 \mathrm{ft}(7 \mathrm{~km}) \mathrm{MSL}$.

The chinook windstorm of 3 November 1975 caused widespread property damage, timber blowdown, and severe clear air turbulence in southwestern Alberta. A detailed analysis of the structure of the surface wind field has been accomplished by combining data from the conventional weather station network with more than 25 supplementary stations. Results of these analyses together with synoptic and satellite data suggest that the windstorm was the result of a large amplitude, hydrostatic lee wave.

During the decade of $1966-75$, a total of over 370 damaging mountain windstorms were reported in the 11 western states resulting in 63 fatalities. The number of reported windstorms has nearly quadrupled from 18 in 1966 to 70 in 1975. The increase in reported windstorms may be a reflection of the growing population trend as people build homes in wind-prone areas at an increasing rate.

Recent applied research programs have developed prediction schemes for the severe downslope windstorm and the bora-Santa Ana windstorm types. A discussion is presented that identifies current operational prediction techniques.

\section{Session 6: Sierra precipitation 1-Analysis}

Orographic effects on Great Basin precipitation

\section{J. G. HOUGHTON}

Historical climatology and snowpack response at Central Sierra Snow Laboratory

\section{J. L. SMITH}

An empirical equation for each month is developed by stepwise regression analysis, expressing the precipitation ratio $\left(\boldsymbol{P}_{o} / \boldsymbol{P}_{q}\right)$ between Great Basin orographic $(o)$ and lowland $(q)$ stations as a function of several parameters. These include effective station elevation difference (rise, distance, and direction), average elevation of station surroundings (5 km radius), blocking effects (length, orientation, and relief) of upwind and downwind mountain barriers, and distance and direction from ocean moisture sources. Parameters are tested individually, in combination with each other, and with the mean monthly Great Basin wind vector to determine their influence on the precipitation ratio.

Precipitation, temperature, and snowpack data were evaluated for the period of record to develop a basis from which to evaluate the effect of precipitation augmentation upon snowpacks at the Central Sierra Snow Laboratory.

Precipitation records for the period 1898-1974 were analyzed. Temperature records were analyzed for the periods for which they were available (1909-17, 1931-52, and 1958-74). Snowpack records adequate for evaluation date from 1945 to 1974 . Maximum, minimum, mean, standard deviations, and coefficients of variation were obtained for yearly, seasonal, monthly, weekly, and daily values for precipitation, temperature, and snowpacks. Precipitation patterns were investigated. Precipitation simulation was used to estimate the effect of snowpack augmentation on maximum flood flows of the American River and on the first and last days 
Snowpack evaporation reduction: It's possible, but is it practical?

\section{J. A. BALDWIN AND J. L. SMITH}

Regionalizing design storms in data sparce areas of California

\section{J. D. GOODRIDGE}

Lake Tahoe water balance

\section{R. A. LIND AND \\ J. D. GOODRIDGE}

Numerical calculations of airflow and cloud cover during winter storm conditions in the Colorado Rockies and the Sierra Nevada

\section{E. C. NICKERSON ET AL.}

of snowpack development. No correlations were found between precipitation for the three snow seasons (fall, winter, and spring). Formulas were developed and tested for separation of precipitation into rain or snow when the only available records listed total precipitation and temperature. Precipitation simulation and snowpack simulation techniques were used to evaluate the increase in snow depth and extension of snowpack melt-out date resulting from precipitation augmentation for a number of aspects and vegetative covers.

Evaporation from snowpacks can be largely eliminated as long as a suppressant can be kept on top of the snowpack. A suppressant is only effective, however, until new snowfall covers it. It again becomes effective when melt of the overlaying snow uncovers the layer to which the suppressant was applied. Estimates of maximum evaporation reduction expected under idealized conditions (had the suppressant been actually applied) are examined using snowpack and meteorological data at the Central Sierra Snow Laboratory for the years 1969 through 1976 . Only schedules of one, two, and three applications of suppressant are examined. More than three applications would not be economically feasible, and large amounts of suppressant would begin to accumulate. With the possible exception of the drought year 1976 (that year was relatively storm-free), only small amounts of evaporation were suppressed because the layer of suppressant was generally soon covered by a new snowfall. Analysis of the number of days between storms at the same geographical area from 1899 to the present suggests that the 8 years examined are typical of the past record; large amounts of evaporation reduction are not to be expected at the sites examined.

Precipitation depth-duration frequency relationships were developed for over 600 recording and 900 nonrecording rain gages in California. Data needed are extreme annual series precipitation for durations of $5,10,15$, and $30 \mathrm{~min}$ and $1,2,3,6,12$, and $24 \mathrm{~h}$; the total annual values for recording gages; and the extreme annual 1, 2, 3, 4, 5, 6, 8, 10, 15, 20, 30, and 60 day and the annual total values for the nonrecording rain gages.

Data analyses use a dimensionless mean precipitation expressed as a percent of average annual precipitation, a dimensionless coefficient of variation to develop a standard deviation. The coefficients of variation and skewness were found to be uniform over a broad range of storm durations. Uniform regions of constant coefficient of variation and skewness were developed covering the entire state.

All design storms can be expressed as a percent of the mean annual precipitation, which can be described in greater detail using the state's entire 7000 rain gages, snow survey records, vegetation distribution, and stream flow patterns.

This paper is a reevaluation of water balance of Lake Tahoe covering the 20-year period of 1958-77 and an inventory of hydrologic records. It is based on an annual summary of all available surface water and evaporation records, as well as all of the available precipitation and snow survey records for the Lake Tahoe Basin. The total surface water inflow, direct precipitation, and the evaporation are estimated and balanced against the total outflow, which is measured by the U.S. Geological Survey.

A time-dependent 15-level sigma system model has been used to investigate the effects of mountainous terrain on airflow, clouds, and snowfall. Calculations have been made over regions $175-250 \mathrm{~km}$ on a side using a $26 \times 26$ grid and horizontal grid lengths of $7-10 \mathrm{~km}$. The linking of dynamical, thermodynamical, and microphysical processes permits an evaluation of the interaction and feedback between airflow and cold cloud microphysics. The suppression of horizontal friction in the thermodynamic equations results in noisier fields of temperature and cold water, but an improved data base is needed before we can determine whether the inclusion of horizontal friction actually results in a better simulation.

\section{Session 7: Sierra precipitation 2-Sierra Cooperative Project}

Report on preliminary data from a multi-Doppler radar study of weather systems in and near the Sierra Nevada

W. R. MONINGER AND

R. CARBONE
During early 1978, two $3 \mathrm{~cm}$ Doppler radars from the Wave Propagation Laboratory and one $5.5 \mathrm{~cm}$ Doppler radar from NCAR participated in the Sierra Cooperative Pilot Project of the Bureau of Reclamation.

The radar portion of the project was designed to study wind fields in convective bands moving across the Sacramento Valley and orographic systems in the Sierra Nevada foothills. The effective coverage of the radars extended $\sim 50 \mathrm{~km}$ in all directions from the center of the triangle. We report on a preliminary analysis of some of the data taken during this study. 
$A$ radar climatology of

Sierra Nevada winter storms

\section{J. L. SUTHERLAND AND C. WISNER}

As part of the Bureau of Reclamation's Sierra Cooperative Pilot Project to develop an efficient technology for snowpack enhancement through weather modification, storms occurring during the 1976-77 and 1977-78 winter seasons are being observed by radar and rawinsondes. From those observations, a radar climatology is being developed.

Results from the 1976-77 winter season show that each storm consisted of at least one convective band, numerous convective cells, and at least one multicell (formed from cell mergers). Bands generally occurred before or during frontal passage, whereas cells and multicells formed behind the front.

Frequency distributions of band and cell echo parameters will be presented, and environmental conditions associated with the development of bands and cells will be discussed. Results from the 1977-78 winter season will be included.

Results will be shown from 2 years of study of satellite infrared and visible observations of Pacific storm systems affecting the Sierra Nevada of California. During the field period of the Sierra Cooperative Program, digital SMS-2 (at $135^{\circ} \mathrm{W}$ ) VISSR (Visible and Infrared Spin Scan Radiometer) data were collected for specific storm events during the December-March time period for the winters of 1976-77 and 1977-78. Data were collected every half hour for $36-48 \mathrm{~h}$ depending on the timing of the storm passing through California.

Results will detail the satellite's capabilities in measuring cloud top temperature of the orographic cloud situated over the Sierra Nevada range. It has been found by some investigators that the cloud top temperature is directly related to its seedability. Comparison of satellitedetermined top temperatures and aircraft-measured top temperatures will be shown.

A second study will show the satellite's capability to observe small-scale (mesoscale) cloud features such as bands and convective elements that occur in these storm systems.

As part of the Sierra Cooperative Pilot Project, observations of the microphysical and dynamical characteristics of storms over the American River Basin area of the Sierra Nevada were made during the 1977-78 winter season. These observations were made with the newly instrumented Super 200 King Air cloud physics aircraft. To compliment the airborne cloud physics data, a mobile ground cloud physics observer collects ice crystal and other data along I-80. To demonstrate the large temporal and spatial variability in Sierra storms, some preliminary data from the storm of 14-15 December 1977 will be presented. Liquid water contents as high as $2.5 \mathrm{~g} / \mathrm{m}^{3}$, droplet concentrations of $300 / \mathrm{cm}^{3}$, ice particle concentrations of $100 / 1$, and vertical updrafts of $6 \mathrm{~m} / \mathrm{s}$ were observed.

The relations among these measurements, the location within the storm, and stage of development of the storm will be discussed. Some preliminary implications of these results will be discussed in regard to artificially enhancing snowfall from these storms.

The Bureau of Reclamation's Project Skywater is conducting a Sierra Cooperative Pilot Project in the American River Basin of California. This is the second season of concentrated study of storm characteristics preliminary to a multiyear randomized seeding experiment. A case study will be presented for the storm occurring on 14-15 December 1977. Data sources will include NWS synoptic information, cloud physics data from University of Wyoming King Air 200, precipitation gages, ice microphysics, SWR-75 radar, and GOES-(West) satellite information. Data will be presented to describe storm structure and characteristics, and possible seeding potential will be discussed.

The Sierra Cooperative Pilot Project is a research experiment to develop a better understanding of the physical processes of precipitation formation and to identify those conditions that provide the best potential for snowpack enhancement by cloud seeding in the Sierra Nevada. A number of important questions need to be resolved before a full-scale randomized experiment is designed and undertaken. In an attempt to answer these questions, preliminary measurements were undertaken in the winters of $1976-77$ and 1977-78. Radar, aircraft, and ground instruments were deployed in and upwind of the American River Basin. Data obtained from these measurements will be used in the ongoing experimental design.
Preliminary meteorological measurements in support of the Sierra Cooperative Pilot Project

\section{VARDIMAN}




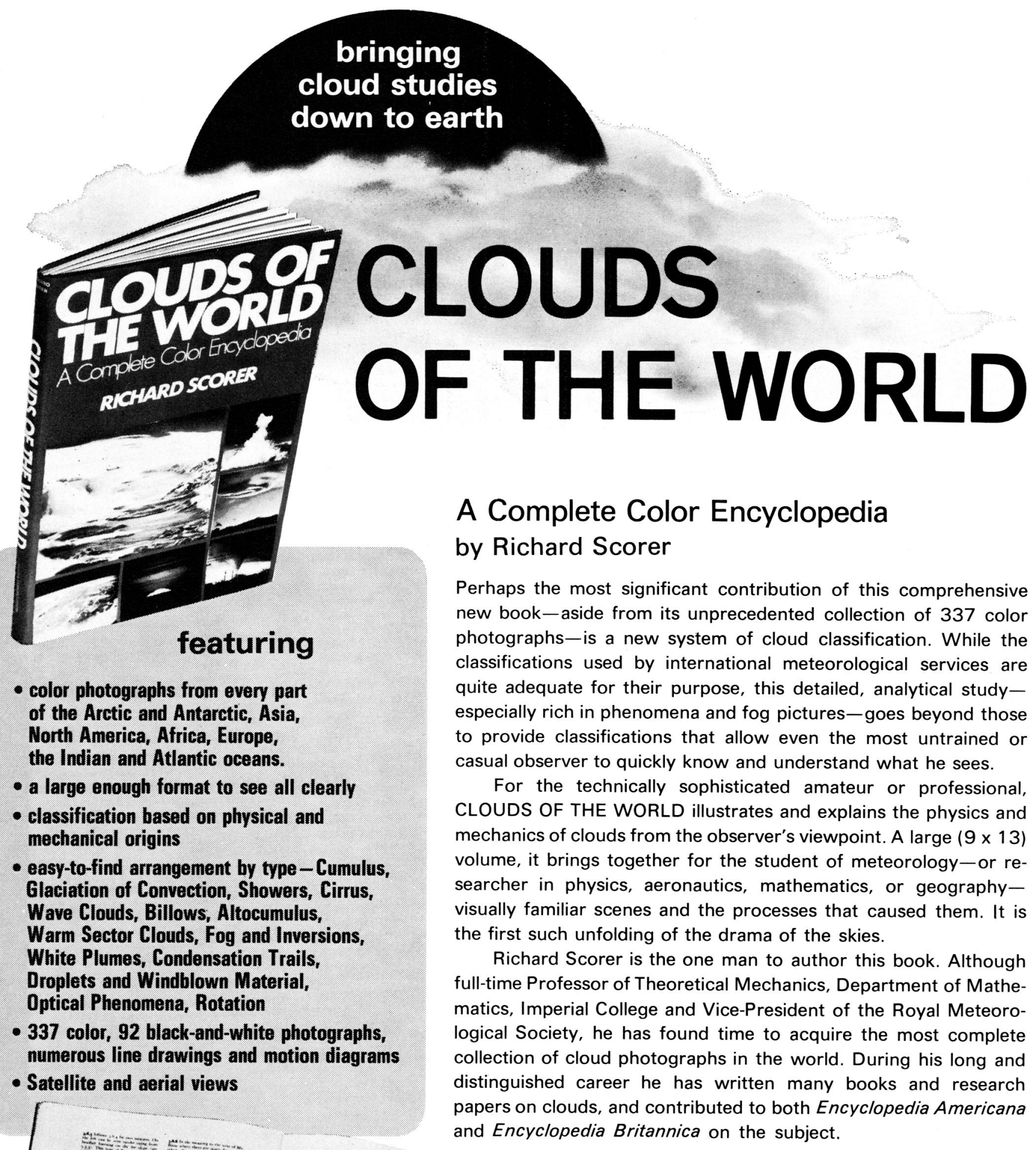

\section{A Complete Color Encyclopedia by Richard Scorer}

Perhaps the most significant contribution of this comprehensive new book-aside from its unprecedented collection of 337 color photographs-is a new system of cloud classification. While the classifications used by international meteorological services are quite adequate for their purpose, this detailed, analytical studyespecially rich in phenomena and fog pictures-goes beyond those to provide classifications that allow even the most untrained or asual observer to quickly know and understand what he sees

For the technically sophisticated amateur or professional, CLOUDS OF THE WORLD illustrates and explains the physics and mechanics of clouds from the observer's viewpoint. A large ( $9 \times 13$ ) volume, it brings together for the student of meteorology-or researcher in physics, aeronautics, mathematics, or geographyvisually familiar scenes and the processes that caused them. It is the first such unfolding of the drama of the skies.

Richard Scorer is the one man to author this book. Although full-time Professor of Theoretical Mechanics, Department of Mathematics, Imperial College and Vice-President of the Royal Meteorological Society, he has found time to acquire the most complete collection of cloud photographs in the world. During his long and distinguished career he has written many books and research and Encyclopedia Britannica on the subject.

The American Meteorological Society is pleased to make this important study available again to all who find fascination in the changing atmosphere.

$\$ 35.00$

Special offer to AMS Members $\$ 31.50$

(10\% discount)

Send your order to:

American Meteorological Society

45 Beacon Street, Boston, Mass. 02108 